\title{
LA ORDEN HOSPITALARIA DE SAN JUAN DE DIOS EN FILIPINAS. SIGLOS XVII Y XVIII
}

\author{
POR \\ ADRIANA ROCHER \\ Universidad Autónoma de Campeche, México \\ adrocher@hotmail.com
}

\section{RESUMEN}

La historia de la orden hospitalaria de San Juan de Dios en Filipinas es poco conocida, en contraste con la profusa historiografía existente sobre la actuación de las diferentes corporaciones eclesiásticas en el archipiélago. Este trabajo pretende estudiar los procesos que permitieron su expansión y desarrollo en las islas, su trabajo hospitalario, el concepto de hospitalidad que le sirvió de guía y las peculiaridades que adoptó el gobierno de sus hospitales y religiosos, situados a miles de kilómetros de su casa matriz en la ciudad de México.

PALABRAS CLAVE: Juaninos; sistema hospitalario; hospitalidad; caridad; Filipinas.

\section{THE ORDER OF ST. JOHN OF GOD IN THE PHILIPPINES. 16TH - 17TH CENTURY}

\begin{abstract}
The history of the Brothers Hospitallers of St. John of God in the Philippines is little known, in contrast to the prolific existing historiography on the performance of the different ecclesiastical corporations in the archipelago. This work tries to study the processes that allowed their expansion and development on the islands, their hospital work, the concept of hospitality that served as a guide and the peculiarities adopted in the management of the hospitals and religious, located thousands of kilometers from their headquarters in Mexico City.
\end{abstract}

KEY WORDS: Juaninos; hospital system; hospitality; charity; Philippines.

Recibido/Received 05-12-2013

Aceptado/Accepted 02-01-2015

\section{INTRODUCCIÓN}

En 1742 el sacerdote fray Juan Manuel Maldonado, miembro de la Orden Hospitalaria de San Juan de Dios, publicó una crónica que tuvo como uno de sus fines rescatar la memoria perdida de la actuación de su instituto en las Islas Filipinas al igual que la de sus varones justos, y así dar pie a que permanecieran "sus loables hechos con el recuerdo, que por lo escrito se hace duradero en la sucesión". ${ }^{1} 270$ años han pasado desde entonces y, para desconsuelo del ánima de fray Juan Manuel, el silencio,

1 Maldonado de Puga, J. M. 1742. Religiosa Hospitalidad por los hijos del Piadoso Coripheo Patriarcha y padre de pobres San Juan de Dios en su provincia de San Raphael de las islas Philipinas: 2. Granada: Imprenta de José de la Puerta. aunque eventualmente interrumpido por uno que otro susurro, sigue imperando en lo que respecta a la historia de los hijos de San Juan de Dios en las Filipinas.

El presente texto pretende aportar su grano de arena a esa historia poco conocida, para lo cual abarcará el proceso de expansión juanino en Filipinas, su gobierno y su trabajo hospitalario propiamente dicho, todo visto bajo el amplio marco del sistema hospitalario establecido por la Corona española en sus colonias americanas y el del concepto de hospitalidad entonces vigente, destacando el sentido que tal actividad pudo tener en las Filipinas de los siglos XVII y XVIII. Debo aclarar que nuestro estudio se detiene antes del último cuarto del siglo XVIII, época de las visitas-reforma emprendidas bajo los auspicios del reformismo carolino, las que marcaron el advenimiento de una nueva etapa en el sistema sanitario a cargo de las órdenes hospitalarias. 


\section{HOSPITALES, HOSPITALARIOS Y HOSPITALIDAD}

Por caridad, amor y misericordia se hizo la redención del género humano, y debajo de estos tres nombres están fundados los más de los hospitales: del amor de Dios, de la caridad y de la misericordia. ${ }^{2}$

Para acercarse a las ideas de hospital y actividad hospitalaria vigentes durante los siglos XVII y XVIII habría que acudir primero al concepto que las significaba y daba sentido: hospitalidad. Brindar hospedaje al peregrino, al viandante, al pobre sin techo, criar niños expósitos y curar a enfermos y heridos eran todas acciones que confluían bajo el amplio paraguas de la hospitalidad y del ser hospitalario.

Desde el siglo IV la identificación de la hospitalidad con el cristiano imperativo de "amar al prójimo como a ti mismo" impulsó la aparición de numerosas instituciones y organizaciones hospitalarias en el seno de la Iglesia; y fue una de ellas la que, entre 1538 y 1539, iniciaría un nuevo camino que con el tiempo llevaría a redefinir la imagen y el carácter de la hospitalidad, al separar la atención y cuidado de los enfermos del asilo y protección a pobres y desvalidos. ${ }^{3}$

La Orden de San Juan de Dios fue la primera organización en ejercer la actividad hospitalaria en el sentido moderno del término y en introducir en sus hospitales de forma sistemática el orden, la limpieza y, sobre todo, la profesionalización en el trabajo de enfermería. Por si fuera poco, los juaninos también tuvieron su particular política de "calidad", política que tuvo como bandera no a la eficacia y la eficiencia, sino el ejercicio pleno de la caridad, apuesta lógica para quien "la misericordia es la madre del hospital y el hospital es el lugar donde se ejercitan sus obras". ${ }^{4}$

La organización fundada por los seguidores de Juan Ciudad, mejor conocido por la posteridad como San Juan de Dios, escogió un terreno prácticamente virgen para sembrar las semillas de su obra y con ello selló su destino. Era, en efecto "la flor que faltaba en el jardín de la Iglesia", 5 un jardín poblado de párrocos, misioneros, predicadores y místicos, pero no de enfermeros. Y que la flor que le faltaba a la Iglesia de Roma era la de la enfermería y no otra quedó manifiesta en su tajante prohibición a que los sacerdotes ocupasen prelacías al interior de la orden juanina y en las limitaciones impuestas para que sus religiosos recibieran las órdenes sacras. ${ }^{6}$

2 Santos, J. [1715] 1977. Cronología hospitalaria y resumen historial del glorioso patriarca San Juan de Dios. T. I: 7. Madrid: Orden Hospitalaria de San Juan de Dios.

3 Si bien suele considerarse a 1572, cuando se erigió canónicamente en Congregación, como el año de fundación de la Orden de San Juan de Dios, sus cronistas suelen remontar esa fundación al momento en que San Juan de Dios recibió el hábito. No hay acuerdo entre los historiadores de la orden juandediana sobre la fecha en que este acontecimiento se dio, aunque las diferencias son mínimas pues mientras que para fray Juan Santos esto ocurrió en noviembre de 1538, Juan Ciudad Gómez sitúa el suceso un año después. Santos, J. T. I: [1715] 1977: 229. Gómez, J. C. 1963. Historia de la Orden Hospitalaria de San Juan de Dios: 21. Granada: Archivo Interprovincial.

4 Santos, J. T. I: [1715] 1977: 7.

Dicho por San Pío V en el breve Salvatori Nostri de 5 de septiembre de 1571 por la que aprobó que la comunidad de los hospitalarios de Juan de Dios se erigiera en congregación religiosa. Citado por Martínez Gil, J. L. 2003. “Execuátur Pontificio. Placet Regio de las Bulas". Archivo Hospitalario 1: 96.

6 El breve de Clemente VIII de 9 de septiembre de 1596 prohibió a los hermanos juaninos el ascenso a las órdenes sacras. Ante la súplica
Pero no sólo el jardín de la Iglesia romana adolecía de tal carencia; el de su católica majestad Felipe II, también. El monarca y sus inmediatos sucesores colocaron bajo su protección a la entonces naciente congregación, asegurándose, eso sí, de poner los candados que asegurasen su dependencia de la Corona y su exclusiva dedicación al trabajo hospitalario. ${ }^{7}$ De esta manera, mediante la real cédula de 7 de abril de 1634 y, principalmente, el auto del Consejo de Indias de 20 de abril de 1652, quedó establecido que la orden de San Juan de Dios y el resto de órdenes hospitalarias ${ }^{8}$ en el desempeño de su particular apostolado estarían sujetas a la vigilancia, visita y corrección de las autoridades civiles y eclesiásticales locales sin importar privilegios ni bulas papales en contrario y no serían dueñas de los hospitales sino solo sus administradores, razón por la cual estos no debían ser llamados conventos ni sus superiores recibir el título de priores. Más aun, limitaron el número de casas de noviciado a sólo las insertas en dichas ordenanzas: para 1634 lo fueron sólo las de Lima, México y Panamá, a las que en 1652 se agregaron las de Santa Fe, Santiago y Potosí. ${ }^{9}$ Aunque varias de estas disposiciones no se cumplieron al pie de la letra, siempre pendieron sobre la cabeza de los juaninos cual espada de Damocles, lista para ser esgrimida en su contra cuando la ocasión lo ameritase.

Otro jardín que parecía esperar la flor cultivada por los hermanos juaninos era el de las islas Filipinas. Por lo menos

de los religiosos Paulo V, por un breve fechado el 12 de abril de 1608, aceptó permitir que por cada casa uno de sus hermanos pudiera tomar el presbiterado y, tres años después, el 7 de julio de 1611, condescendió a elevar ese número a dos. Urbano VIII, mediante el breve Circunspecta Romani Pontificis de 18 de abril de 1628, prohibió que los sacerdotes pudieran ocupar prelacías al interior de la orden, y el 17 de julio del mismo año estableció que el hermano que quisiera ordenarse como sacerdote debía tener al menos 10 años cumplidos como religioso juanino. Por bula del 12 de marzo de 1629 reafirmó los mandatos anteriores. Al respecto, véase las bulas de Urbano VIII reproducidas en Archivo General de Indias (en adelante AGI), Filipinas 86, N. 12, imágenes 27-31. Las de Clemente VIII, Paulo V y comentarios a las de Urbano VIII en Parra y Cote, A.1987. Bulario de la Orden Hospitalaria de San Juan de Dios: 97, 104-112, 165-169. Granada: Orden Hospitalaria de San Juan de Dios.

7 Felipe II apoyó la erección de los hermanos de Juan de Dios como congregación, pero se opuso a que se constituyera como orden religiosa, pues eso hubiera significado su independencia de los Ordinarios y su dependencia de un gobierno central con sede en Roma. Aunque no pudo evitar lo segundo, sí fue un actor fundamental para su supresión en 1592 y, cuando tocó a su hijo y sucesor Felipe III pedir su restauración, lo hizo una vez que los hospitalarios se dividieron en dos grandes congregaciones, una con sede en Italia y otra en España, y que esta última no dudara en ponerse bajo el patrocinio de la monarquía hispana, que es lo mismo que decir bajo su dominio. Al respecto, véase Gómez, J. C. 1963: Caps. VIII, XII-XIV y XVII.

8 Además de la orden de San Juan de Dios, tuvieron presencia en la América española las órdenes hospitalarias de San Hipólito, la de Nuestra Señora de Belem, la de Los Canónigos Reglares de San Agustín del Instituto de San Antonio Abad y la de San Camilo. Véase Santos, J. T. I: [1715] 1977: 77; Muriel, J. T. 1990. Los hospitales de la Nueva España. T. I: 10-15. México: UNAM-Cruz Roja Mexicana; y Bautista Sandoval, J. E. 2011. "Las casas de la Buena Muerte una búsqueda, una permanencia”. Bitácora 23: 32-36.

9 Rocher Salas, A. 2005. La provincia del Espíritu Santo de San Juan de Dios de Nueva España, en A. Gutiérrez Escudero, y M. L. Laviana Cuetos (Coords.). Estudios sobre América, siglo XVI-XX: 1302, 1303. Sevilla: Asociación Española de Americanistas. La real cédula de abril de 1652 puede encontrarse en AGI, Filipinas, 86, N. 12, imágenes 21-27. 
así lo dejan ver las repetidas instancias que desde principios del siglo XVII sus autoridades, tanto civiles como eclesiásticas, elevaron ante el Rey y su Consejo de Indias a fin de que los juaninos acudieran a esos remotos dominios del imperio hispano para hacerse cargo de sus hospitales. Y, sin embargo, para estas primeras instancias Madrid tuvo siempre la misma respuesta: no.

\section{ESTAS PARTES TAN REMOTAS ADONDE VALE MUCHO UN ESPAÑOL}

América representó una oportunidad dorada para aquellos deseosos de poblar el paraíso con nuevas almas, por lo que los hijos de Juan de Dios no dudaron en participar de la empresa haciendo suyo el llamado de su amado patriarca: "por los cuerpos a las almas". ${ }^{10}$ Al Nuevo Mundo llegaron en 1596, siendo el puerto de Cartagena de Indias su primer destino, y menos de una década después sentaron sus reales en Nueva España. ${ }^{11}$

El terreno que habrían de arar los religiosos juaninos distaba de ser un páramo yermo, pues por carencia de hospitales no sufría el virreinato novohispano. Sin embargo, estas instituciones, por lo general, se encontraban en manos de aprendices o improvisados, tanto en cuanto a la gestión hospitalaria como en lo relativo al trabajo de enfermería. ${ }^{12} \mathrm{Y}$ era ahí donde los juaninos y el resto de órdenes hospitalarias podían marcar la diferencia, por lo que no es de extrañar que en las siguientes décadas fueran puestos bajo su administración la mayor parte de los hospitales del virreinato.

Sin embargo, la expansión de los hospitalarios de Juan de Dios tuvo en Filipinas un territorio que se le resistió por años, lo que no se debió a la falta de ganas de los religiosos o de los habitantes del archipiélago. El primero intento al respecto data de 1616, cuando fray Pedro Egipciaco, general de la congregación española de los hospitalarios del venerable Juan de Dios $^{13}$ solicitó y obtuvo de Felipe III una real cédula fechada el 1 을 de febrero de 1617, por la cual el monarca comunicó al Presidente y oidores de la Audiencia y al Arzobispo de Manila el envío de 10 religiosos de la congregación, en el entendido de que podrían "servir y ser de provecho en su ministerio y espiritualidad". Junto con la notificación iba una orden:

que los amparéis, favorescáis y ayudéis acomodándolos y ocupándolos como os pareciere más conveniente para que se consiga el fin que se ha tenido de que vayan a esas islas. ${ }^{14}$

Nada se menciona de hospitales ni muchos menos de su entrega a los herederos del "loco" de Granada, por mucho que un siglo después los cronistas juaninos reivindicasen a esa real cédula como la base legitimadora de sus derechos

\section{Gómez, J. C. 1963: 19.}

11 Ibídem, 136, 162-166.

12 Muriel, J. T II: 1991: 7, 8.

13 Juan de Dios fue beatificado por Urbano VIII el 21 de septiembre de 1630 y, finalmente, canonizado por Alejandro VIII el 16 de octubre de 1690 .

14 Trasunto sin fechar incluido en el expediente que en 1622 promovieron los hermanos juaninos fray Bruno de Ávila y fray Juan de Gamboa para que se les entregasen el Hospital Real de Españoles de Manila y el de las Islas Molucas. AGI, Filipinas, 80, N. 93, imagen 57. Por causas que desconocemos, dicha misión nunca llegó a concretarse. sobre distintos hospitales del archipiélago en esa primera etapa fundacional. ${ }^{15}$

Pero las ansias fundadoras de los juaninos fueron siempre por delante de las autoridades y de la burocracia de Madrid. Ya antes del mandato filípico habían cruzado a las Filipinas fray Juan de Gamboa y fray Lucas de los Ángeles, movidos por el deseo de ejercer el apostolado propio de su instituto socorriendo en cuerpo y alma a los enfermos del hospital real de españoles de Manila. ${ }^{16}$ Sin embargo, al entonces gobernador Juan de Silva le parecieron muy pocos dos religiosos para tan ambicioso proyecto, eso sin contar con el hecho de que el hospital en cuestión estaba bajo la administración de los franciscanos descalzos de la provincia de San Gregorio y "no haber orden de Su Majestad para innovar en esto". ${ }^{17}$

Pese a sus limitaciones, el trabajo de los dos solitarios juaninos rindió algunos frutos, por lo menos aquellos provenientes de los árboles locales, pues en fechas cercanas a 1616 la Audiencia de Manila y los cabildos civil y eclesiástico escribieron al rey para pedirle que enviase una misión de religiosos de Juan de Dios a efectos de que se hiciesen cargo de los hospitales de la ciudad. La petición no fue escuchada $y$, como sus promotores pensaron que la causa de su fracaso había estado en que dichas cartas y las informaciones que les acompañaron fueron hechas "de por sí" y no de "oficio", para 1621 volvieron a la carga. ${ }^{18}$

15 Cuando en 1622 fray Bruno de Ávila y fray Juan de Gamboa pidieron se les entregase la administración de distintos hospitales en Filipinas, además de nunca mencionar la real cédula de 1617, explícitamente señalan que sus intenciones de ejercer las obras de caridad propias de su instituto no habían tenido efecto porque las informaciones dirigidas al Rey sobre la conveniencia de su administración hospitalaria no se habían hecho de oficio, afirmación que no concuerda con la existencia de una real orden destinada a traspasar a los hermanos de Juan de Dios los hospitales de las islas. AGI, Filipinas, 80, N. 93, imagen 34. Sin embargo, en la crónica de fray Juan Santos, publicada en 1715 , a la real cédula de febrero de 1617 se le añade una frase: "os mando que los favorezcáis, amparéis y ayudéis, acomodándolos y ocupándolos en la entrega de los hospitales según y cómo os pareciere más conveniente", adenda que en 1742 también hizo fray Juan Manuel Maldonado, aunque no exactamente igual: "os mando que los favorezcáis, amparándolos en la entrega de los hospitales según y cómo os pareciere más conveniente..." (los dos subrayados son míos, para resaltar la frase añadida). Por cierto, ambos cronistas, tal vez por un error al leer el texto original, señalan el 10 de febrero como fecha de expedición de la citada real cédula. Santos. T. II: [1715] 1977:587; Maldonado de Puga, J. M. 1742: 24.

16 AGI, Filipinas 80, N. 93, imagen 12. El hecho debió ocurrir en 1611 aproximadamente, pues en 1621 tanto fray Bruno de Ávila como fray Juan Gamboa mencionan que tenía 10 años que éste hizo el viaje de Nueva España a Filipinas. En dicha información no se hace referencia explícita a fray Lucas de Ángeles, sino sólo a que fray Juan emprendió la aventura con un compañero, cuya identidad aparece en una patente del Comisario General de Nueva España de 1641. Maldonado de Puga, J. M. 1742: 42.

17 Petición de fray Juan de Gamboa para que se haga información de oficio a favor de su Orden. Manila, julio de 1621. AGI, Filipinas 80, N. 93, imagen 12.

18 De lo actuado en 1616 y la respuesta que pudo tener por parte del Consejo de Indias no hemos encontrado evidencia. De hecho, asumimos que tales eventos ocurrieron en ese año debido a que en 1621 se hizo referencia a que tales informaciones se habían hecho cinco años atrás. Petición de fray Juan de Gamboa para que se haga información de oficio a favor de su Orden. Manila, junio de 1621. AGN, Filipinas 80, N. 93, imagen 34. 
Entonces los juaninos llamaron a testificar en favor de la conveniencia de su administración hospitalaria a médicos, cirujanos, barberos y connotados vecinos, informaciones que fueron acompañadas de cartas de los cabildos civil y eclesiástico y de la Audiencia de Manila, mismas que dibujan un panorama bastante oscuro de la situación de los hospitales del archipiélago, estrategia comprensible habida cuenta su intención de resaltar la necesidad del trabajo de los hijos del venerable Juan de Dios. Aun así, estos testimonios nos permiten situar mejor el papel desempeñado o que se esperaba desempeñaran las instituciones hospitalarias dentro del complejo marco de la presencia española en Filipinas.

La mayor y más importante porción de hospitales se encontraban en manos de los franciscanos descalzos, a cargo de los hospitales reales de españoles y naturales de Manila, y de otro hospital en Baños, aunque hay que aclarar que su participación en la atención de los enfermos se limitaba al cuidado de sus almas, porque el de sus cuerpos se encomendaba a mayordomos y personas seglares asalariadas; los dominicos administraban el hospital de San Gabriel, exclusivo para la atención de Sangleyes, y el resto de las instituciones hospitalarias eran atendidas por soldados activos o retirados y, principalmente, por seglares bajo salario. Y el trabajo de estos últimos constituyó el punto crítico en el que los juaninos fundamentaron su reclamo de la conveniencia de que se les entregasen los hospitales de Filipinas, en particular el Hospital Real de Españoles de Manila y el de Las Molucas.

Según sus críticos, los asalariados tenían tres grandes inconvenientes: sus salarios y traslado a Filipinas constituían un pesado lastre para la real hacienda; no eran especialistas, pues su ejercicio de la enfermería era sólo temporal, "cosa de prestado, y que uno es hoy y otro mañana"; ${ }^{19}$ y, más importante aún, porque

como personas seglares y que no se mueven a asistir en los dichos hospitales por caridad sino por la paga que se les hace no acuden con la puntualidad que los enfermos han menester. ${ }^{20}$

Caridad. Esa es la palabra clave para los juaninos, la Audiencia, los cabildos civil y eclesiástico de Manila y los testigos que a título personal participaron con sus declaraciones en la integración de la información presentada por los religiosos hospitalarios. Así, los franciscanos descalzos no ejercían al ministerio de la hospitalidad de "justicia ni de obligación sino ... de caridad;"21 los seglares asalariados que desempeñaban el trabajo de enfermería no lo hacían "por caridad sino por su interés,"22 por cuya causa no tenían "caridad en regalar y curar a los dichos enfermos"23 lo que

19 Declaración del médico Juan Pereyra. Manila 10 de Julio de 1621. AGN, Filipinas 80, N. 93, imagen 40.

20 Interrogatorio formado a petición de fray Juan de Gamboa para que se haga información de oficio a favor de su Orden. Manila, julio de 1621. AGI, Filipinas 80, N. 93, imagen 13.

21 El Cabildo Eclesiástico de Manila al Rey. Julio de 1622. AGI, Filipinas 80, N. 93, imagen 5.

22 Petición del hermano fray Bruno de Ávila para que se entreguen los hospitales a la Orden de Hermanos Hospitalarios de Juan de Dios. 1621. AGI, Filipinas 80, N. 93, imagen 2.

${ }^{23}$ Declaración de don Juan de Leos. Manila, 14 de julio de 1621. AGI, Filipinas 80, N. 93, imagen 20. ocasionaba que muchos enfermos optaran por "abandonar el hospital por la poca cura, caridad y regalo" que había en él; ${ }^{24}$ todo lo cual tendría solución con los juaninos que atendían a los enfermos "con mucho amor, caridad y suavidad" 25 pues ese trabajo además de hacerlo por "caridad lo profesan por voto de acudir por obligación a las obras de misericordia". ${ }^{26}$

En la unánime exaltación de la caridad como principal motivo y motor de la hospitalidad, definida esta como "obra de misericordia", 27 puede leerse el desprecio todavía vigente hacia quienes desempeñaban un oficio, en este caso la enfermería, compelidos por el prosaico fin de recibir un salario y no por la elevada causa de servir a cualquiera de las dos majestades, Dios y el Rey, o a ambas inclusive. Pero aun en esta mirada de antiguo régimen es posible distinguir una ventana por la que ya se asoma la modernidad, pues los testigos, aparte de la caridad, hicieron también la apología del valor de la experiencia y especialización juandediana en el trabajo de enfermería y de administración hospitalaria.

Si bien entre todos los testigos es general el señalamiento de que los juaninos son los más idóneos para hacerse cargo del hospital real de españoles de Manila porque "su instituto y profesión ${ }^{28}$ se refieren a este de hospitalidad" ${ }^{29} \mathrm{o}$ porque "siempre han tratado en esto [la hospitalidad] y ... el curar enfermos y regalarlos", 30 son los médicos, cirujanos y barberos, es decir, los especialistas en la atención y tratamiento de enfermos, los que más específicos son en cuanto a las limitaciones que personal improvisado en las tareas de enfermería significan para el quehacer hospitalario, lo cual les sirve para resaltar las bondades del trabajo juanino y la forma en que su perfil encajaba con el del personal especializado necesario para cubrir los requerimientos del principal hospital del archipiélago. Así, son prolijos en describir el orden y limpieza en los centros juandedianos, lo bien que administran su medicación a los enfermos y como, en general, cumplen las órdenes de los médicos, mientras que en el hospital real de los españoles, en donde todos estos testigos ejercen o ejercieron durante años, han presenciado cosas como enfermos a quienes se les administran purgas $y$ jarabes sin que ningún médico lo hubiera ordenado, o que en día de purga se les diera a comer carne de vaca o se les dejase levantar a beber agua -ambas cosas contraindicadas según los conocimientos médicos de entonces-, lo que traía

24 Declaración del Br. Don Luis Dehencia Saldoval. Manila, 14 de julio de 1621. AGI, Filipinas 80, N. 93, imagen 16.

25 Declaración de Dr. Don Juan Pérez de Rivaguda. Manila, 1ㅇ de julio de 1621. AGI, Filipinas 80, N. 93, imagen 36.

$26 \quad$ Ibídem, imagen 37.

27 Fray Juan Gamboa y los testigos presentados en la información usan con frecuencia la expresión "obra de misericordia" para definir el carácter del trabajo desempeñado por los religiosos juaninos "como adscritos y obligados por voto a las dichas obras espirituales y corporales, por cuyo mérito y no por otro del mundo, se pueden ejercer las de curar enfermos". Información a favor de la Hospitalidad de San Juan de Dios. Manila, julio de 1621. AGI, Filipinas 80, N. 93, imágenes $11,12,33,37$ y 39.

28 Aquí al hablar de profesión se refieren al cuarto voto de hospitalidad que profesan los hospitalarios de Juan de Dios, y no de profesión como sinónimo de oficio.

29 Carta del Cabildo de la Ciudad de Manila al Rey. 2 de agosto de 1622. AGI, Filipinas 80, N. 93, imagen 10.

30 Declaración de Don Lucas de Vergara Gaviria. Manila, 14de julio de 1621. AGI, Filipinas 80 N. 93, imagen 28. 
como fatal resultado el que los soldados del tercio y vecinos pobres que entraban al hospital murieran "por falta de regalo y de cuidado con ellos y de quien administre y haga lo que el médico y cirujano ordenare". ${ }^{31} \mathrm{Y}$ la pérdida que eso significaba resultaba irreparable para esas "partes tan remotas adonde vale mucho un español". ${ }^{32}$

La siempre precaria presencia española en Filipinas mantuvo una dependencia constante del envío de soldados que, de manera forzada o voluntaria, llegaban cada año provenientes de la Nueva España; y esto, por supuesto, siempre y cuando no hubiera accidentes que impidieran al galeón completar su trayecto hacia Manila. Eran vidas valiosas, altamente demandadas para la defensa de un territorio complejo por su geografía y sus habitantes nativos, por no hablar del asedio de los tradicionales enemigos holandeses o ingleses. Valiosas también por el costo que para las arcas reales suponía su traslado. Y, perder esas vidas en un hospital, no por el efecto de la gravedad de unas heridas sufridas en batalla o porque sus cuerpos fuesen incapaces de sobreponerse a las inclemencias de un medio ambiente enteramente distinto del que provenían, sino como resultado de una mala atención, era un lujo que los españoles no podían o, mejor dicho, no debían permitirse. Es así como, desde esta perspectiva, la hospitalidad tenía un nada desdeñable papel que jugar en la preservación del imperio español en esos remotos confines.

Los franciscanos descalzos de la provincia de San Gregorio poco hicieron en su defensa, pues no fueron más allá de pedir que no les quitasen unos hospitales que habían fundado y sostenido durante más de 25 años. Sin embargo, su escueto alegato fue suficiente para obtener del Consejo de Indias un lacónico pero rotundo "Que no se haga novedad en Filipinas y se deje la hospitalidad a los religiosos descalzos de San Francisco como hasta ahora lo han tenido". ${ }^{33}$

Que los vientos no soplaban en dirección favorable al barco juanino quedó de manifiesto con la real cédula de 16 de octubre de 1626, dictada en respuesta a una petición del gobernador Juan Niño de Tavora en el sentido de que los hermanos de Juan de Dios se hiciesen cargo de los hospitales del archipiélago, en vista de que no eran "administrados con el cuidado que conviene". La resolución del Rey ignoró olímpicamente -como diríamos hoy- la solicitud de Niño de Tavora, limitándose a encargarle que "pongáis de vuestra parte todo cuidado en que los pobres tengan la mayor comodidad que se pudiere y sean socorridos". ${ }^{34}$

Y así fue como fray Juan de Gamboa hubo de empacar sus cosas y su ánimo de fundador para regresar a la Nueva España con las manos vacías. Y con él los hospitalarios del venerable Juan de Dios tuvieron que guardar sus afanes expansionistas o caritativos, o ambos, según como quiera verse, para esperar mejores tiempos, tiempos que parecieron llegar de la mano de Sebastián Hurtado de Corcuera, gobernador de Filipinas de 1635 a 1644.

31 Declaración del cirujano Alonso Jiménez Durán. Manila, 11 de julio de 1621. AGI, Filipinas 80, N. 93, imágenes 43-45.

32 Declaración de Don Miguel Garcetas. Manila, 14 de julio de 1621. AGI, Filipinas 80, N. 93, imagen 31.

33 Consejo de 27 de marzo de 1724. AGI, Filipinas 80, N. 97, imagen 5 .

34 Maldonado de Puga, J. M. 1972: 38, 39.
No tenía ni un año en la silla de gobernador del archipiélago filípico cuando Hurtado de Corcuera decidió separar a los franciscanos de la administración de los hospitales reales de españoles de Manila y Cavite, dejándoles los de Baños, Camarines y otros mientras esperaba nuevas instrucciones desde Madrid, las que rogaba fueran en el mismo sentido de una petición: que de esos hospitales se hicieran cargo los hermanos hospitalarios del ya para entonces beato Juan de Dios o, en su defecto, lo hicieran clérigos seculares auxiliados por un mayordomo seglar. ${ }^{35}$

El deseo de Hurtado de Corcuera por llevar juaninos a las Filipinas no nació de su contemplación de la precaria situación de los hospitales de la región, pues ya desde su estancia previa en Nueva España, adonde estuvo en tránsito hacia su nuevo destino, albergaba esa idea. Entonces solicitó a fray Juan Pobre, visitador de los juaninos en América por nombramiento del general de la congregación española, le proporcionase seis religiosos, entre los que se contasen cirujanos y enfermeros, para que pasasen en su compañía a Filipinas, que él se encargaría de sustentarles y de conseguir del Rey las licencias necesarias para una fundación. Sin embargo, esa primera petición no tuvo efecto toda vez que fray Juan Pobre se encontraba ocupado con la visita general y, sobre todo, porque carecía de la autoridad suficiente para autorizar el traslado. Cinco o seis años después Hurtado de Corcuera renovó su solicitud, la que corrió con mejor suerte y le fueron enviados dos religiosos, a los que en un año se unieron otros dos. ${ }^{36}$

La defensa franciscana de sus derechos sobre los hospitales que les fueron arrebatados impidió al gobernador entregarlos a los juaninos, por lo que en su defecto los envió a Cavite y, mientras uno se quedó a cargo del hospital del puerto, los otros se embarcaron con los galeones que iban al socorro de Terrenate. A la vuelta de Terrenate uno de los religiosos pasó un tiempo en el hospital de Camboanga, en las Islas de Mindanao, pero luego se unió a dos de sus hermanos que habían fundado un pequeño hospital de convalecientes en Bagumbayan, cerca de la iglesia de Nuestra Señora de Guía en las afueras de Manila, gracias al donativo de una casa hecho por una piadosa bienhechora. ${ }^{37}$

El apoyo de Hurtado de Corcuera fue continuado por su sucesor Diego de Fajardo, llegado a las Islas en 1644, pero ambos condicionaron las licencias que les otorgaron, lo mismo para la entrega del hospital de Cavite como para la fundación del de Bagumbayan, a que los frailes juaninos consiguieran la autorización de Madrid para seguir a cargo de tales instituciones hospitalarias, requisito indispensable tanto porque así lo ordenaba la legislación vigente como porque los religiosos no contaban con la licencia real para estar en Filipinas, pues la que los llevó al archipiélago, otorgada

35 El gobernador de Filipinas al Rey. Manila, 30 de Junio de 1636. AGI, Filipinas 8, R. 3, N. 50, imágenes 1-5.

36 Aunque Hurtado de Corcuera menciona que fue fray Juan Pobre quien hizo el envío de los 4 religiosos, el padre Juan Manuel Maldonado reproduce las patentes que hicieron posible el traslado de los primeros dos religiosos, las que fueron expedidas por fray Joseph Medrano, a la sazón Comisario General de Nueva España de la Orden del Beato Juan de Dios, con fecha 20 y 27 de febrero de 1641 . Maldonado de Puga, J. M. 1742: 42-46.

37 Informe de Sebastián Hurtado de Corcuera hecho a pedimento del Consejo de Indias. Córdoba, 10 de julio de 1653. AGI, Filipinas 86, N. 12, imágenes 33-37. 
por el virrey Don Diego López Pacheco, Marqués de Villena, fue por sólo dos años y con el fin específico de realizar una "cobranza y diligencia de unos papeles y hacienda perteneciente a la dicha religión". ${ }^{38} \mathrm{Y}$ ahí, nuevamente, fue donde las cosas se estancaron.

Aunque no hemos encontrado el resolutivo final a la solicitud de licencia hecha por fray Francisco Magallanes en su calidad de fundador del hospital de convalecientes de Bagumbayan, creemos que no debió ser favorable considerando el hecho de que las sucesivas opiniones del fiscal del Consejo de Indias fueron siempre contrarias a dicha petición, con todo y que iba avalada por el gobernador, el Cabildo civil y la Audiencia de Manila. De hecho, existe un borrador de una real cédula fechada en el año de 1653 en el que Su Majestad niega su permiso y ordena que se dé marcha atrás en la donación y fundación del hospital de Bagumbayan. ${ }^{39}$

¿Por qué el favor del que los juaninos gozaban entre las autoridades civiles y eclesiásticas de Filipinas fue inversamente proporcional al que el Rey y su Consejo de Indias le dispensaron, por lo menos durante estos años? La respuesta se encuentra principalmente en el afán de la Corona española por mantener a la Iglesia y a sus distintas corporaciones bajo parámetros que permitieran su control por parte del Estado.

La Orden del venerable Juan de Dios había tenido una historia accidentada a pesar de sus pocos años de vida: aceptada como Congregación en 1571, para 1586 obtuvo el reconocimiento como orden religiosa, sólo para ser suprimida y puesta bajo el control de los obispos en 1592. A partir de entonces, los juaninos comenzaron el camino de la restauración, que inició con la dolorosa ruptura entre los hermanos de Italia y España, a lo que siguieron coyunturas mejores que permitieron que en 1619 la Congregación Española de los hospitalarios de Juan de Dios alcanzase la condición de orden religiosa y, con ella, el derecho a gobernarse libre de la sujeción a la autoridad episcopal. ${ }^{40} \mathrm{~A}$ partir de entonces, los juaninos comenzaron su lucha para que ese y otros privilegios que sucesivos papas les concedieron les fueran reconocidos tanto en España como en América, y en ese afán radicó el que la Corona lo pensara dos veces antes de continuar promoviendo la expansión juandediana hacia sus territorios indianos.

Nuestro ya conocido fray Juan Pobre fue el encargado de llevar a América las bulas papales que los eximían de la autoridad de los obispos, iniciándose entonces un conflicto similar al que los Ordinarios sostenían con las órdenes mendicantes encargadas de la administración parroquial de los

38 La licencia otorgada por el Virrey López Pacheco fue para los dos primeros religiosos que cruzaron a Filipinas; de la que llevaron los otros dos no he encontrado referencia. Los trámites relativos a los hospitales de Cavite y Bagumbayan pueden verse en Maldonado de Puga, J. M. 1742: 42-82. Y AGI, Filipinas 86, N. 12. Los términos de dicha licencia partieron de la creencia de las autoridades juaninas de que fray Juan Gamboa, en su paso por Filipinas, había sido favorecido con donaciones en metálico y en especie lo suficientemente abundantes como para fundar un hospital de convalecientes en Bagumbayan. Sin embargo, en la información que promovió junto con fray Bruno de Ávila, Gamboa nunca hizo referencia a tales hechos. AGI, Filipinas 80, N. 93.

39 AGI, Filipinas 86, N. 12, imágenes 39-41.

40 Al respecto, véase la bibliografía inserta en la nota 7. nativos americanos: la exención de la autoridad episcopal se limitaba al gobierno interno de las órdenes religiosas, pero no a su función como párrocos -para el caso de los mendicantes- o como hospitalarios -cuando de los juaninos se trataba-; el problema radicó en que mientras unos, los obispos, reducían el campo al que se refería el concepto de "observancia regular", los otros, los regulares, lo ensanchaban hasta casi reventar sus propios resortes..$^{41} \mathrm{Y}$ si la Corona pasó todo el siglo XVII armando el entramado legal e institucional que sujetaría a los mendicantes con funciones parroquiales a la autoridad diocesana, no dejó de actuar en consecuencia con los juaninos y el resto de las órdenes hospitalarias con presencia en América. De esta manera, de 1630 a 1652 fueron hilvanándose reales cédulas y ordenanzas con esa finalidad, con lo que se consiguió el objetivo de cerrar definitivamente la puerta a cualquier reclamo de independencia en la gestión hospitalaria por parte de orden religiosa alguna. ${ }^{42}$

Pero hasta antes de que la ordenanza de 20 de abril de 1652 pusiera el último cerrojo al candado de la sujeción de las órdenes hospitalarias, desde el Consejo de Indias se les miró con desconfianza y se echó mano de la lupa para analizar cada una de sus peticiones, no fuera a ser que se le escapase algún beneficio o privilegio de más. Y es ese marco lo que explica las sucesivas resoluciones del Consejo o los pareceres adversos de sus fiscales con respecto a los juaninos de Filipinas, informes donde fue continua la mención de su afán por fundar conventos y eximirse de la autoridad de los Ordinarios. ${ }^{43}$

Una vez cerrado el paso a su independencia y resignada a su destino, no hubo más obstáculos para el desarrollo de la orden del beato Juan de Dios que los que ella misma o sus particulares circunstancias le impusieran. De ahí que, cuando la Santa Mesa de la Misericordia decidió cederle su hospital, todos los involucrados, dentro y fuera de Filipinas, estuvieron listos para dar paso a un proceso de entregarecepción, rápido y libre de controversias.

La Hermandad de la Santa Misericordia fue fundada en 1594 a instancias del padre Juan Fernández de León, sacerdote cuya vocación de servicio a los pobres y enfermos convivió con su pasión por la vida ermitaña. ${ }^{44}$ Como es de suponer dado el perfil de su fundador, la hermandad de la Misericordia tuvo como objetivo principal la realización de obras de caridad en beneficio de los más desvalidos, lo que la llevó a erigir en 1596 un hospital con título homónino, ${ }^{45}$ en el que durante décadas se atendieron pacientes de todas clases, colores y sexos, característica que lo diferenciaba del

41 Al respecto, véase la obra de Pérez Puente, L. 2010. El concierto Imposible. Los concilios provinciales en la disputa por las parroquias indígenas (México, 1555-1647). México: IISUE-UNAM.

42 Véase lo comentado al respecto en el apartado Hospitales, hospitalarios y Hospitalidad.

43 Consejo de Indias, 16 de marzo de 1624. AGI, Filipinas 80, N. 97 , imagen 8. AGI, Filipinas 86, N. 12, imágenes 3 y 4.

44 San Antonio, J. F. de 1738: 198. Díaz Trechuelo, L. 1997. “La Casa de la Misericordia de Manila". En Actas del XI Congreso del Instituto Internacional de Historia del Derecho Indiano. T. IV: 71. Buenos Aires: Instituto de Investigaciones de Historia del Derecho.

45 Maldonado de Puga, J. M., 1742: 84. Pese a las diferentes versiones sobre el origen del hospital de la Misericordia, nos hemos inclinado por la que da el cronista juanino, toda vez que la propia hermandad apunta en la misma dirección cuando señala que "desde su fundación ha sustentado el hospital de su nombre". Petición de la Mesa de la Misericordia sobre cesión de su hospital a los hermanos de San Juan de Dios, 1659. Filipinas 86, N. 13, imagen 1. 
resto de hospitales de Manila, donde el que no era para españoles, era para naturales y el que no para sangleyes. ${ }^{46}$ Sin embargo, llegada la cuarta década del siglo XVII una serie de desafortunados incidentes, como terremotos y la pérdida de navíos que hacían la ruta Acapulco-Manila, dejaron el edificio y las finanzas del hospital maltrechos, tanto como los bolsillos de sus habituales bienhechores, los cuales no dejaron de resentir los efectos de la crítica coyuntura por la que atravesaban las islas. Sintiéndose incapaces de sostener simultáneamente dos obras de gran envergadura, como lo eran el hospital y el Colegio de Santa Isabel, en donde, además de educar a las hijas de los españoles que podían pagar 60 pesos anuales por su pupilaje, se hacían cargo de doncellas huérfanas y sin recursos, ${ }^{47}$ la Santa Mesa de la Hermandad decidió ceder su hospital a los juaninos, por parecerles que eran quienes tenían la capacidad y los recursos necesarios para garantizar la continuidad de la institución. ${ }^{48}$

El 9 de marzo de 1656 la hermandad de la Misericordia y los hermanos del beato Juan de Dios acordaron las condiciones para la cesión, y en un lapso de 3 meses los apoderados de la hermandad consiguieron todas las autorizaciones y licencias requeridas por parte de las autoridades civiles y eclesiásticas locales, lo que les puso en condiciones de solicitar a Madrid la licencia real, la que el Rey les concedió el 5 de diciembre de 1659, bajo la condición de que "esto sea y se entienda con las calidades contenidas en el dicho auto, que aquí va inserto, proveído por los del dicho mi Consejo en 20 de abril de 1652". ${ }^{49}$

46 Según el cronista de la provincia de San Gregorio, fray Juan Francisco de San Antonio, el hospital de la Misericordia fue fundado por uno de sus hermanos legos, fray Juan Clemente, y que al erigirse la Hermandad de la Misericordia el hospital quedó bajo su administración corporal, mientras que la espiritual la tuvo la provincia de San Gregorio, razón por la cual comenzó a llamársele Hospital de la Misericordia de los Padres Franciscanos. Sin embargo, la crónica de fray Francisco de Santa Inés señala que el hospital fundado por fray Juan Clemente fue el de Santa Ana, bautizado por el vulgo como hospital de la Misericordia de los Padres Franciscanos, y que más tarde recibiría el título de Hospital de los Naturales. En 1634 el hospital volvió a mudar su nombre al de San Lázaro, por haber albergado a los leprosos que llegaron en una embarcación proveniente del Japón. La versión de Santa Inés fue retomada décadas más tarde por fray Domingo Martínez. San Antonio, J. F. de. 1738. Chrónicas de la apostólica Provincia de San Gregorio de Religiosos Descalzos de N. P. S. Francisco en las Islas Filipinas, China, Japón, \&: 198. Manila: Imprenta de la Provincia. Santa Inés, F. de. 1892. Crónica de la Provincia de San Gregorio Magno de religiosos descalzos de N. P. S. Francisco en las Islas Filipinas, China, Japón, etc., escrita en 1676. T. I: cap. XXXV, 379-386. Manila: Litografía de Chofre y Compañía. Martínez, D. 1756. Compendio Histórico de la Provincia de San Gregorio Magno de Philipinas de Religiosos Menores Descalzos de San Francisco: 29. Madrid: Imprenta de la viuda de Manuel Fernández y del Supremo Consejo de la Inquisición. Por su parte, Francisco Guerra considera que fue el hospital de Santa Ana o de los Naturales el que dio paso al hospital de la Santa Misericordia, versión que recoge posteriormente Solange Alberro. Guerra, F. 1994. El hospital en Hispanoamérica y Filipinas, 1492-1898: 552, 553. Madrid: Ministerio de Sanidad y Consumo. Alberro, S. 2005. Apuntes para la historia de la Orden Hospitalaria de San Juan de Dios en la Nueva España-México, 1604-2004: 145. México: El Colegio de México - Orden Hospitalaria de San Juan de Dios.

47 Díaz Trechuelo, L. 1997. T. IV: 74.

48 Maldonado de Puga, J. M. 1742: 84, 93-97.

49 Ibídem, 100. Además de su parcial reproducción en la crónica del padre Maldonado, las diligencias relativas a la entrega del hospital de la Misericordia a los hospitalarios de Juan de Dios se encuentran en AGI, Filipinas 86, N. 13 y AGI, Filipinas 22, R. 9, N. 47.
La real cédula de Felipe IV tuvo un significado mayor que la mera validación de la escritura de entrega del hospital de la Misericordia a los hermanos hospitalarios del Beato Juan de Dios; en los hechos, permitió legalizar la estancia de los juaninos en Filipinas, algo que no habían conseguido después de décadas de intentar sentar raíces en el lugar, lo que hizo posible que continuasen con su obra en Manila y de paso, en Cavite también. Por otra parte, su aceptación por parte de los religiosos, con todo y la cláusula relativa al auto de abril de 1652, dejó claro su reconocimiento de que ninguna bula, breve ni privilegio papal estaba por encima del regio patronato; luego entonces, procedieron a guardar en el baúl de los deseos imposibles su preciada independencia en el desempeño de la administración hospitalaria.

\section{LA TRABAJOSA Y PERENNE TAREA DE LA HOSPITALIDAD}

El accidentado camino que hubieron de recorrer los hermanos juaninos antes de que la Corona aceptase su posesión del hospital de la Misericordia hizo que el inicio de su obra hospitalaria en Filipinas fuera más que modesto. A finales de 1641, fray Andrés de San José, por órdenes del gobernador Sebastián Hurtado de Corcuera, fundó o, mejor dicho, refundó, un hospital en el puerto de Cavite. Hablo de refundar porque el hospital existía desde varias décadas atrás, pero cargaba sobre sus espaldas una historia harto azarosa: a veces en manos de mayordomos y diputados seglares, en otras bajo administración franciscana; en ocasiones en casa propia, en otras en una prestada, la institución no conocía de estabilidad ni de continuidad. ${ }^{50}$ De ahí que fray Andrés se considerase su fundador, pues fue su trabajo el que levantó un hospital en las casas reales del puerto, dotado con 10 camas que tenían como sus principales ocupantes a marineros españoles y a esclavos de las reales galeras. ${ }^{51}$

Poco duró el hospital en las casas reales, que en realidad no eran tales sino sólo una casas arrendadas para alojar a los gobernadores en sus visitas al puerto, así que cuando en 1645 su verdadero dueño las reclamó, frailes y esclavos a su servicio debieron trasladarse a unas "tiendezuelas"; los enfermos, por su parte, quedaron más que nunca a la bendición de Dios, porque en las tiendas no había lugar para ellos. Ante las súplicas de fray Francisco de Magallanes, sucesor de fray Andrés como prior del hospital, el gobernador Diego de Fajardo accedió a concederles un camarín propiedad de Su Majestad, ubicado junto al pueblo de Cavite. ${ }^{52}$

50 Fue fundado en 1591 por los franciscanos descalzos de la provincia de San Gregorio. Martínez, D. 1756: 30. En 1619, a causa de su mucha pobreza, comenzó a recibir la ayuda de la Real Hacienda. Maldonado de Puga, J. M. 1742: 58. En 1633 la Audiencia de Manila reportó que del hospital se hacían cargo los diputados y mayordomos seglares, y que en tiempos del gobernador Juan Niño de Tavora se le concedieron fondos especiales para la construcción de un edificio nuevo de piedra, lo que aún no se había ejecutado. Manila, 6 de julio de 1633 . AGI, Filipinas 21, R. 7, N. 22, imágenes 1 y 2. Finalmente, en 1636 el gobernador Sebastián Hurtado de Corcuera comunicó al Rey que lo había quitado de las manos de los franciscanos y que tenía el proyecto de mandarlo establecer en unas casas que solían servir de alojamiento a los gobernadores durante sus visitas al puerto. Manila, 30 de junio de 1636. AGI, Filipinas 8, R. 3, N. 50, imágenes 4 y 5.

51 Maldonado de Puga, J. M. 1742: 53, 54. AGI, Filipinas 86, N. 12 , imagen 6.

52 Maldonado de Puga, J. M. 1742: 67- 69. AGI, Filipinas 86, N. 12, imágenes 9-11. 
Con la colaboración estatal, consistente en 200 pesos anuales, las rentas provenientes de algunos solares en alquiler y de una estancia en Leyton, fray Francisco de Magallanes pudo construir un nuevo edificio para albergar el hospital. Sin embargo, "el batidero del mar y otros accidentes" acabaron con él en 1682, iniciándose así un ciclo de derrumbes y reconstrucciones que para 1742 ya iba por la cuarta vuelta. ${ }^{53}$ Para entonces las finanzas del hospital estaban en números rojos, pues aunque compartía con el hospital de Manila una encomienda de 500 tributarios, la antigua ayuda que le proporcionaba el erario público de 200 pesos anuales tenía décadas de haber cesado y sus propiedades, como la estancia y los solares, no rendían mayor cosa. Por eso no es de extrañar que el hospital en lugar de aumentar su capacidad de atención hospitalaria lo que viera crecer fueran sus deudas, al punto que el 30 de octubre de 1766 una real cédula ordenó a las autoridades de las islas que procurasen los medios necesarios para librarle de tan pesada carga, mandato que para 1775 aún no se cumplía. ${ }^{54}$

Por otra parte, el hospital de convalecientes de Bagumbayan, en las afueras de Manila, tuvo una vida corta, como corta fue su capacidad de atención hospitalaria, que no pasó de unas cuantas camas debido a las pocas rentas que tuvo para su sostenimiento, las que estuvieron limitadas a las limosnas que recaudaban sus religiosos. Pese a sus escasos recursos materiales, el hospital mantuvo ese carácter de "asilo universal", 55 propio de las instituciones juaninas, pues a él se acogían a convalecer tanto los enfermos que abandonaban el hospital real de españoles, como eclesiásticos, soldados, vecinos e incluso los naturales, cuyo hospital se encontraba también extramuros de Manila, sólo que al otro extremo. ${ }^{56}$ Además tuvo la intención de acoger y criar niños expósitos propósito que, aunque desconocemos si llegó a ponerse en práctica, muestra la pervivencia del antiguo concepto de hospitalidad que incluía el asilo y albergue a los desamparados. ${ }^{57}$

Incierto era el futuro de este hospital, debido a la reticencia de Madrid para aprobar nuevas fundaciones por parte de órdenes religiosas, particularmente de las hospitalarias, pero al final no fueron decisiones de la metrópoli las que llevaron a su desaparición, sino la cesión del hospital de la Misericordia a la orden del aún beato Juan de Dios, la cual prefirió trasladar a sus religiosos de Bagumbayan a la Misericordia, paso lógico si se considera la importancia de esa institución habida cuenta su mayor tamaño y recursos, lo que permitiría a los frailes juaninos hacer más amplio su abrazo caritativo.

53 Maldonado de Puga, J. M. 1742: 66-70. Alberro, S. 2005:139.

54 Manchado López, M. M. "Religiosidad femenina y educación de la mujer indígena en Filipinas. El beaterio-colegio de la madre Paula de la Santísima Trinidad". Revista de Indias LIX-215: 181.

55 Ese concepto y otros similares fueron usados repetidas veces por los individuos y corporaciones llamados a testificar en alguna de las informaciones promovidas por los hermanos de San Juan de Dios. Por ejemplo, véase Filipinas 86, N. 45, imágenes 13,17 y 23 . Filipinas, 146, N. 20, imágenes 309, 329, 337 y 345.

56 Informe de Sebastián Hurtado de Corcuera hecho a pedimento del Consejo de Indias. Córdoba, 10 de julio de 1653. AGI, Filipinas 86, N. 12, imágenes 34,35 y 37.

57 Maldonado de Puga, J. M. 1742: 73-77. Véase también Licencia del Gobernador Sebastián Hurtado de Corcuera para la fundación del hospital de convalecientes de Bagumbaya. Manila, 14 de abril de 1644. AGI, Filipinas 86, N. 12, imágenes 11-14.
Apenas recibieron el hospital, los juaninos pusieron manos a la obra: reformaron el edificio para dejar habilitadas tres salas, con 12 camas cada una, para que "con separación se pudieran servir enfermos, hombres y mujeres, españoles, indios y morenos". ${ }^{58}$ Para 1676 la capacidad de atención del hospital se había elevado a 52 camas, pero su clientela potencial tuvo un crecimiento de igual o mayor proporción, toda vez que el hospital de los naturales, llamado "de San Lázaro", ya no existía. Para colmo de males, un terremoto ocurrido el 15 de marzo del mismo año dejó en ruinas iglesia, hospital y convento, lo que obligó al superior juanino a solicitar le ayuda real, la que le fue otorgada en forma de una encomienda de 500 tributos, cuyas rentas debían destinarse a la reparación de las instalaciones dañadas. ${ }^{59}$

Las endémicas dificultades de la región a causa de la frecuente interrupción del tráfico comercial con la Nueva España, la permanente situación de alerta militar ante enemigos internos y externos y las catástrofes producto de temblores y terremotos, motivaron que lo que había sido una solución a una coyuntura específica se volviera una porción indispensable del financiamiento no sólo del hospital de la Misericordia, sino también del de Cavite. De esta forma, en los años subsecuentes los frailes no dejaron de solicitar la renovación de los 500 tributos de encomienda, merced que pudo haberse interrumpido durante la segunda mitad del siglo, toda vez que para 1776 ya no aparece como parte de los ingresos del hospital. ${ }^{60}$

No obstante sus limitaciones económicas, el inacabable círculo de construcción, ruina y reconstrucción de sus edificios y su dificultad para hacer crecer el número de sus religiosos, los juaninos siguieron acudiendo "con infatigable desvelo a la trabajosa y perenne tarea de la hospitalidad" ${ }^{61}$ De esta manera, el hospital de la Misericordia continuó creciendo en cuanto a capacidad de atención hospitalaria: para 1724 contaba con cuatro salas, una nombrada San Rafael para la atención de españoles, con 10 camas; la sala de Nuestra Señora de la Soledad para mujeres morenas y naturales, en la que había veinte camas; la sala de San Juan de Dios, algo apartada del resto por estar dedicada a mujeres españolas, tenía sólo cuatro camas y, por último, la sala de San Roque, para morenos y naturales, con 21 camas. ${ }^{62}$ Para 1742 en las tres salas generales había más de 60 catres, además de otras divisiones que servían para alojar a personajes distinguidos como sacerdotes, colegiales de los cuatro colegios de la ciudad y otros connotados vecinos de Manila. Para dar una idea de la afluencia de pacientes al hospital, baste contar los aproximadamente 8,000 pobres que ingresaron a sus salas de 1730 a $1742 .{ }^{63}$ También debe hacerse notar que la capacidad de atención del hospital no hay que medirla

58 Maldonado de Puga. 1742: 101.

59 Petición de fray Marcos de Mesa, visitador y vicario provincial de las islas Filipinas de la Orden de San Juan de Dios. AGI, Filipinas 86, N. 45, imágenes 21-23. Manila, junio 19 de 1676. Sobre la concesión de encomienda, véase AGI, Filipinas 12, R. 1, N. 16.

60 Manchado López, M. M. 1999: 179, 180.

61 El Provincial de la Provincia de San Nicolás de Tolentino de Agustinos Descalzos de las Islas Filipinas Fray Andrés de San Fulgencio. Manila, 16 de junio de 1735. AGI, Filipinas 146, N. 20, imagen 345.

62 Inspección hecha al hospital de San Juan de Dios por el escribano público Francisco Antonio del Río, 5 julio de 1724. AGI, Filipinas 146, N. 20, imágenes 32-35.

63 Maldonado de Puga, J. M. 1742: 103. 
únicamente por el número de camas, pues era usual que hubiera enfermos en los suelos. Así, para 1776 el prior del hospital calculaba en 130 o 140 el número de sus pacientes usuales, 60 en las camas y 70 u 80 en el suelo, cantidad que podía elevarse a más de 200 "en tiempos catarrales y de epidemias". ${ }^{64}$

Pero como religiosos que eran, los juaninos también se ocuparon de labrar el espacio físico que habría de servirles para atender a la sanación de las almas de sus enfermos o de los devotos de su orden. Aunque el conjunto que les cedió la hermandad de la Misericordia tenía una capilla, esta era pequeña, cerrada al hospital y, por lo tanto, sin posibilidad de servir de puente de enlace entre los religiosos y la sociedad manileña. Para cumplir este objetivo, el apoderado de la hermandad de la Misericordia solicitó y obtuvo del arzobispo de Manila la licencia para que los frailes pudieran

tener iglesia con puerta a la calle, tocar campanas, decir misa, enterrar y administrar los santos sacramentos a los que por devoción quisieren, de la manera y como lo hacen en España. ${ }^{65}$

Ya con la anuencia episcopal, los juaninos levantaron una iglesia y su casa habitación, las que cayeron víctimas de un terremoto en 1662, lo que dio pie a un ambicioso proyecto de reconstrucción, el cual no llegó a buen fin pues nuevamente en 1676 los temblores hicieron de las suyas y arruinaron lo que se había avanzado. ${ }^{66}$ Fray Marcos de Mesa emprendió la tarea de reconstruir iglesia y convento, edificaciones que lograron resistir varios terremotos, hasta que en 1727 su ruina era tal que obligó a plantear su reedificación, pues el techo amenazaba con venírsele encima a sus ocupantes. ${ }^{67}$ La nueva iglesia se dedicó el 10 de mayo de 1732, y el acontecimiento fue celebrado con ocho días de grandes festejos en los que tomaron parte las autoridades civiles y eclesiásticas junto con todas las órdenes religiosas presentes en las islas. Fue un gran momento que sirvió a las juaninos para hacer visible el lugar que ya tenían en el concierto de la Iglesia y la sociedad filipinas, un lugar que sus propios demonios internos habían hecho peligrar durante las primeras décadas del siglo XVIII. ${ }^{68}$

Gobierno peculiar de la Santa Provincia del Arcángel SAN RAFAEL

El título con el que fray Juan Manuel Maldonado de Puga nombró el capítulo XIII de su crónica no puede ser más indicativo de la realidad institucional de los juaninos de

64 Manchado López, M. M. 1999: 179.

65 Licencia otorgada por el Arzobispo de Manila a 11 de mayo de 1656. AGI, Filipinas 86, N. 13, imágenes 61-63. Maldonado de Puga, J. M. 1742: $97,98$.

66 Maldonado de Puga, J. M. 1742: 101, 102. AGI, Filipinas 86, N. 45.

67 Maldonado de Puga, J. M. 1742: 102. Inspecciones del hospital de San Juan de Dios realizados el 5 de julio de 1724, el 21 de agosto de 1727 y el 18 de febrero de 1728. AGI Filipinas 146, N. 20, imágenes 35, 107, 108 y 123 . Para 1776 la Iglesia, el convento y el hospital estaban nuevamente en mal estado, particularmente el tejado y la bóveda de la iglesia. Manchado López, M. M. 1999: 179.

68 Una minuciosa relatoría de los ocho días de festejos que siguieron a la dedicación de la iglesia de San Juan de Dios se encuentra en Maldonado de Puga, J. M. 1742: 120-136.
Filipinas: "Gobierno Peculiar de esta Santa Provincia"; y es que si algo tuvo de distintivo ese gobierno fue, justamente, su peculiaridad, particularidad, especificidad o como prefiera llamársele a la serie de elementos que diferenciaron a la provincia de San Rafael de Filipinas del resto de las provincias americanas de la Congregación española de la Orden de San Juan de Dios, algunos de los cuales no sólo ignoraron las legislaciones indiana y juanina vigentes, sino que incluso llegaron a ser abiertamente contrarios a ellas.

La complejidad del armado institucional para las provincias americanas juaninas estuvo marcado por su paralelismo en el tiempo con el diseño de la propia estructura organizacional de la Congregación española de San Juan de Dios, ambos procesos, a su vez, simultáneos a la construcción del edificio normativo con el que el Estado español dio cuerpo al sistema hospitalario regentado por órdenes religiosas. Esa triple conjunción llevó a que las contradicciones y desvíos abundasen en esta primera etapa fundacional, desvíos que con el tiempo fueron haciéndose costumbre y la costumbre se hizo norma, norma no escrita pero que en la práctica supo imponer su ley a la que sí estaba escrita y sancionada por la legislación vigente.

Cuando la curia central juanina en España advirtió la dificultad de gobernar directamente a sus cada vez más numerosos hospitales en la América española decidió nombrar un Comisario General de Indias, con los mismos poderes y autoridad que el general en España, bajo cuyo gobierno se sometió a sus hospitales y religiosos indianos. Creada en 1626, la Comisaría General de Indias tuvo una existencia efímera pues desapareció a consecuencia de los dictados de la real cédula de 7 de abril de 1634, que obligaron a crear tres comisarías generales para América: una en Nueva España, otra en Perú y una más en Tierra Firme, cuyos titulares, nombrados directamente por el general de la congregación española, tendrían para sus respectivas áreas de gobierno la misma autoridad que previamente se había depositado en el Comisario General de Indias. ${ }^{69}$

La apertura de noviciados en América tuvo como secundario e indeseable efecto el inicio de la batalla entre gachupines y criollos por el poder, conflicto que no terminó con la decisión de la curia juandediana de nombrar directamente a los Comisarios Generales, dejando a los capítulos provinciales autoridad únicamente para elegir a los priores de los distintos conventos-hospitales. La confrontación resultó tan encarnizada que incluso, según las crónicas juaninas, llegó a ocurrir que el primer Comisario General de la Nueva España, fray Juan Pobre, fuera envenenado por sus propios súbditos. $^{70}$

El ascenso a la Comisaría General de fray José Medrano, criollo novohispano, agudizó el problema al punto de mantener virtualmente separada a los juaninos de la Nueva España de su matriz española. El objetivo de Medrano era perpetuarse en el cargo, y para conseguirlo procuró convencer a la Corona, al virrey y al general juanino de la conveniencia de elegir a los comisarios generales en los capítulos provinciales. Poco le faltó para salirse con la suya: llegó a convocar un capítulo provincial en 1644, donde por

69 Rocher Salas, A. 2005: 1302- 1304.

70 Santos, J. T. II: [1715] 1977: 157-158. Fray Juan Pobre no murió a consecuencia del veneno, a pesar de que sus secuelas las llevó consigo hasta el final de sus días. 
supuesto fue electo comisario general, capítulo en el que además creó cinco vicarías provinciales para las regiones más apartadas de su provincia, entre las cuales estaba la de Filipinas. Al final, Medrano fue depuesto por las autoridades de la congregación española y prácticamente todas sus reformas fueron anuladas; sólo pervivió la referida a Filipinas, que siguió rigiéndose por vicarios provinciales incluso con posterioridad a la desaparición de la Comisaría General de la Nueva España.

El vicario provincial tuvo la misma autoridad sobre sus súbditos que el comisario general, a excepción de otorgar las dimisorias a aquellos religiosos que pretendiesen el ascenso a las órdenes sacras. Siguiendo la tónica de los gobiernos juaninos, donde el provincial era a la vez superior del principal convento de la provincia, el vicario provincial se desempeñaba también como prior del hospital de Manila. Si bien sus atribuciones no incluían la de nombrar al prior del hospital de Cavite, así lo hizo en la mayor parte de los casos, pues los nombrados desde México rara vez se trasladaron a Filipinas "por lo dilatado del viaje y muchos gastos". ${ }^{71} \mathrm{EI}$ primero en ostentar el título de vicario provincial fue fray Francisco de Magallanes, si bien los juaninos de Filipinas a quien reconocieron como a su fundador fue a fray Andrés de San José, sacerdote profeso, lo que en primera instancia debió haberlo inhabilitado para ocupar el priorato del hospital de Cavite, pues entonces estaban ya vigentes los breves de Urbano VIII prohibiendo a los sacerdotes detentar prelacía alguna dentro del gobierno juanino. ${ }^{72}$ Pero en fin, qué podía esperarse si quien lo había nombrado, el Comisario General de la Nueva España, fray Joseph Medrano, era también sacerdote. Pero si el nombramiento de San José podría explicarse por la confusión de estos primeros años, el de fray Marcos de Mesa, electo vicario provincial en 1669, es simplemente incomprensible: con todas sus letras, el cronista Maldonado narra que "gobernó hasta el de 1682, en que falleció ordenado de sacerdote". ${ }^{73}$ Que tal cosa era contraria a la normativa vigente se aprecia en los casos de fray Antonio de Robles, quien gobernó de 1684 a 1687 o el de fray Domingo de Santa María, vicario provincial de 1690 a 1692, ambos separados de su función por la misma razón: "se ordenó de presbítero y cesó en el cargo". ${ }^{74}$

Impedir el gobierno de prelados inhabilitados por la legislación juanina para ocupar sus cargos no era cosa que preocupase a la Corona o a sus funcionarios, por mucho que el derecho eclesiástico tuviera la condición de derecho supletorio en los territorios del Rey de España; pero evitar que se obviase la legislación real sí era su función y, sin

\footnotetext{
71 Maldonado de Puga, J. M. 1742: 192.

72 Véase nota 6. Sobre la condición de sacerdote de fray Andrés de San José, véase Maldonado de Puga. 1742: 44, 49.

73 Ibídem: 197. Pudiera pensarse que Maldonado quiso expresar que Mesa recibió in extremis las órdenes sacras, pero en otras partes y contextos de su crónica en que hizo referencia a él siempre lo describió como religioso sacerdote. Ibídem: 70 .

74 Ibídem: 198. El caso de fray Juan Ángel, antiguo prior del hospital de La Habana, ilustra la aplicación de la prohibición a los sacerdotes juaninos de ocupar prelacías en su orden en tiempos anteriores al del gobierno de fray Juan de Mesa en Filipinas. Una vez ordenado sacerdote a mediados de los 60's del siglo XVII, Ángel fue trasladado al hospital de Campeche pero ya no en calidad de prior. Al respecto véase Rocher Salas, A. 2010. La disputa por las almas. Las órdenes religiosas en Campeche, siglo XVIII: 164. México: CONACULTA.
}

embargo, ahí también cedieron ante la particularidad del "gobierno peculiar" de los juaninos filipinos. Ya desde la real cédula de abril de 1634 se había prohibido la apertura indiscriminada de noviciados de la orden de Juan de Dios en las Indias Occidentales, otorgando esta atribución a un número limitado de casas, condición que fue confirmada en el auto del Consejo de Indias de abril de 1652 en donde, si acaso, se aumentó de tres a seis el número de casas con derecho a poseer noviciado, casas entre las que no se incluyó ninguna de Filipinas. Y, sin embargo, los prelados de las Filipinas

(desde los primeros sujetos fundadores), usando de las facultades que se les comunicaron, siempre admitieron a aquellos pretendientes de quien juzgaron vocación verdadera y, bien instruidos según el orden de nuestro noviciado, se les dio el hábito". ${ }^{75}$

Así, desde fray Andrés de San José, que en 1642 anunció su intención de "ir recibiendo a la religión algunas personas que quieren recogerse a bien vivir en servicio, cura y regalo de los pobres", hasta 1757, cuando a instancias del cronista y capellán, fray Juan Manuel Maldonado de Puga, la curia generalicia de la Orden autorizó la erección de noviciado en su convento de Manila, con lo cual sería posible "por fin crear religiosos los cuales, como hijos de la referida casa le tengan amor y también a las otras casas que dependen de ella", la provincia de San Rafael dio el hábito a quienes y cuantos quiso obviando la legislación vigente. ${ }^{76}$ Más aún, la concesión incluida en las Constituciones de la Orden de la Hospitalidad de San Juan de Dios, con todo y la expresión "por fin" inserta en ella, pareciera revelar que incluso la propia curia juanina ignoraba -o quería ignorar- ${ }^{77}$ que los juaninos de Filipinas llevaban más de un siglo formando a sus propios cuadros.

Pero donde se aprecia en mayor proporción el carácter peculiar de la provincia de San Rafael es en su presumida condición de provincia. Es posible observar en las crónicas sobre la historia general de la orden de San Juan de Dios, tanto las antiguas como otras más recientes, el hecho de que usan la expresión "Islas Filipinas de la Provincia de la Nueva España", sin otorgarle el título de provincia. ${ }^{78}$ Por otra parte, de haberse constituido en provincia, los juaninos filipinos habrían tenido el derecho a elegir a sus autoridades en capítulo, a tener noviciado -no de hecho, sino de derecho- y a enviar procurador en su representación a los capítulos generales. ${ }^{79}$

Para el tránsito a la condición de provincia debieron mediar mandatos del capítulo general de la congregación española de la orden de San Juan de Dios, bulas papales y

\footnotetext{
75 Maldonado de Puga, J. M. 1742: 190, 191.

76 Constituciones de la Orden de la Hospitalidad de San Juan de Dios ... reimpresas en 1799: 238.

77 Hay que tener presente que la crónica de fray Juan Manuel Maldonado fue escrita para informar al general de la Congregación española sobre la historia y avatares de la provincia de San Rafael, por lo que en primera instancia la curia de la orden debió tener conocimiento de esa continuada práctica. Maldonado de Puga, J. M. 1742: 2.

78 Por ejemplo, véase a Gómez, J. C. 1963: 307; y Santos, J. T. II: [1715] 1977: 700.

79 Ésta última decisión recaía en los Comisario Generales, que para el caso de las Indias eran sólo los de Nueva España -del que dependía Filipinas-, Perú y Tierra Firme, y en sus respectivos definitorios. Constituciones de la Orden de la Hospitalidad: 111, 112.
} 
reales cédulas dándole el pase regio a aquéllas. Pero de nada de esto dan cuenta ni Maldonado ni ningún cronista o historiador de la Orden. En específico, la crónica de Maldonado obvia cualquier información relativa a la erección de la provincia juanina de Filipinas y a la elección de San Rafael como su patrono protector, detalle que nunca pasa inadvertido en las crónicas de las órdenes religiosas.

He podido ahorrarme estas últimas disquisiciones respecto a la posible constitución o no de una provincia religiosa para los juaninos de Filipinas, pues basta con mirar el título de su superior para saber que no lo era: vicario provincial, es decir, el que representa al provincial y así ejerce sus funciones. ${ }^{80}$ Ahora bien, ¿cómo?, ¿cuándo?, ¿dónde?, ¿por qué? y ¿quién o quiénes fueron los autores de la "creación" de la provincia de San Rafael? Hasta aquí los avances de mi investigación solo me permiten aventurar una hipótesis.

A reserva de lo que pueda arrojar una investigación documental más profusa, hasta ahora la primera referencia a la provincia de San Rafael la encontramos para 1703, hecha por fray Francisco Baluyo en su búsqueda por obtener la concesión de una limosna de vino y aceite para el hospital de Manila. ${ }^{81}$ Sin embargo, en ese tiempo y en los años subsiguientes tal denominación convivió con otras que aludían simplemente a los hospitales o a la orden de San Juan de Dios en Filipinas. ${ }^{82}$ Habría que esperar a 1728 para que su uso se hiciera sistemático por parte de las autoridades juaninas de Filipinas; entonces fray Antonio de Arce llevaba dos años como vicario provincial y fray Juan Manuel Maldonado uno como capellán. ${ }^{83}$

Muchos fueron los éxitos de fray Antonio de Arce al frente de los juaninos filipinos: reedificó iglesia, hospital y convento; frenó las disensiones internas y externas que tanto habían minado el prestigio de la orden en las islas, al punto de marginarla de las juntas generales en donde se reunían los prelados de las diferentes provincias religiosas con asiento en Manila y también del novenario que se rezaba anualmente para rogar por el feliz viaje de las naos que hacían la carrera de Acapulco; y, lo más importante, según su panegirista fray Juan Manuel Maldonado, devolvió la concordia, dignidad y buen porte a sus súbditos y a sus claustros y, con ellos, restauró el prestigio y el buen nombre de toda la provincia. ${ }^{84}$

Maldonado, constituido en la mano derecha de fray Antonio, comenzó a tramitar frente a la curia de su orden

80 Vicario: En general es la persona que ejerce las funciones de otra en todo o en parte por delegación y nunca con carácter propio. Martínez Ruiz, E.1998. Diccionario de Historia Moderna de España. I. La Iglesia: 264. Madrid: Istmo.

81 AGI, Filipinas, 297, N. 21, f. 1.

82 Así, mientras en 1703 fray Francisco Baluyo se dio el título de "presbítero y procurador general de la Orden y Hospitalidad de Nuestro Padre San Juan de Dios en la provincia del Señor San Rafael de estas Islas", en 1716 fray Fernando de Torremocha usó para sí mismo el título de "Procurador General del Orden de San Juan de Dios", al solicitar la confirmación de la prórroga de la limosna de vino y aceite. AGI, Filipinas, 297, N. 21. Y en 1727 fray Antonio del Niño Jesús echó mano del título de "Presidente del Convento y Hospital de mi Padre San Juan de Dios, Procurador General de estas islas" para tramitar la renovación de la encomienda.

83 Por el momento no he podido encontrar cuándo finalizó su mandato Arce. El año de llegada de Maldonado como capellán se puede ver en AGI, Filipinas 146, N. 20, imágenes 158, 159.

${ }^{84}$ Maldonado de Puga, J. M. 1742: 202-205. en Madrid que los juaninos de Filipinas se pusieran bajo la jurisdicción directa del Padre General, separándose definitivamente de la Comisaría General de la Nueva España. El argumento principal de Maldonado no era nuevo, pues ya lo había enarbolado un siglo antes fray Joseph Medrano, aquél Comisario General que convocó a un capítulo provincial sin la autorización de sus autoridades en Madrid y del cual vio la luz la vicaría provincial de Filipinas: según Maldonado, la distancia que los separaba de su matriz en México era un obstáculo para su buen gobierno y para la pronta atención de los asuntos y necesidades que demandaban la autoridad del Comisario General novohispano. ${ }^{85}$

En aras de cumplir tan caro objetivo, Maldonado orquestó toda una campaña de la que formó parte la crónica escrita por el propio fray Juan Manuel, quien manifiesta en el proemio de su obra que actuó impulsado por el "hecho de ser indispensable informar a N. Rmo. P. General, que careciendo de puntual razón de lo que es esta provincia, así lo previene". ${ }^{86}$ En su texto, Maldonado hace el panegírico del trabajo de Arce al frente de la "provincia" de San Rafael, refiriéndose a él como su restaurador y atlante, justificando sus más de 13 años en el cargo, y no los tres que se supone le hubieran correspondido, refugiándose en la costumbre de "mantener por largo tiempo a los sujetos cuya prudencia y religioso modo de aquesta [sic.] distinción los hizo dignos"; 87 costumbre que, por cierto, sólo había operado para los casos de fray Francisco de Magallanes (1644-1662), fray Marcos de Mesa (1669-1682) y fray Francisco Hurtado (1711-1720), este último, cabe señalarlo, muy lejano de la definición de sujeto prudente y religioso que el propio Maldonado apunta como característica propia de aquellos prelados que se reeligieron continuamente, pues el mismo cronista señala que en su tiempo decayó notablemente la provincia. $^{88}$

Bajo esta perspectiva, la reinvención discursiva de la "provincia de San Rafael" habría constituido el preludio de la campaña por la separación del gobierno de los juaninos filipinos de su matriz novohispana y su posible constitución, ahora sí, en provincia independiente de hecho y de derecho, permitiendo a sus prelados el control absoluto de la misma pues, en la práctica, las provincia religiosas gozan de una independencia casi total. Sin embargo, dos hospitales no hacen provincia, y el argumento de la distancia aplicaba igual o peor incluso, para el recorrido Madrid-Manila que para el México-Manila. De ahí que sus continuados esfuerzos tuvieran magros resultados: si bien el Padre General y su definitorio en Madrid decidieron poner bajo su protección a sus hijos de Filipinas, esto fue sólo en cuanto a darles la autoridad para abrir noviciado, pero al mismo tiempo ordenaron que para su gobierno temporal debía "quedar la provincia bajo la jurisdicción del Padre Comisario General [de la Nueva España], del mismo modo que hasta el presente ha estado". ${ }^{89}$ Así, el acto de admitir "bajo su protección a dicha provincia" [de San Rafael] quedó en el plano discursivo,

85 Gómez, J. C.1963: 292. Los argumentos de Medrano, diseminados en varias peticiones y en los resultados del capítulo al que convocó, pueden encontrarse en AGI, Indiferente General 3076.

86 Maldonado de Puga. 1742: 2.

87 Ibídem: 191.

88 Ibídem: 198-200.

89 Constituciones de la Orden de la Hospitalidad ...: 238. 
mismo lugar al que se confinó la existencia de la provincia de San Rafael de las Islas Filipinas.

\section{CONSIDERACIONES FINALES}

La "invención" de la provincia de San Rafael de la Religiosa Hospitalidad de San Juan de Dios tal vez haya sido producto de la ambición de unos cuantos hombres, que una vez despegados sus pies de la tierra fueron incapaces de ver la imposibilidad de materializar sus sueños de grandeza, toda vez que las columnas en que se basaban, los dos hospitales de Manila y Cavite, eran insuficientes para sostener el peso de un edificio del tamaño de una provincia religiosa. La provincia de San Rafael puede verse también como una manifestación del afán de poder de los prelados situados en áreas marginales quienes, so pretexto del aislamiento y la distancia, pugnaban por desvincularse de sus autoridades superiores a fin de convertirse ellos mismos en la única e indiscutible autoridad. Igualmente es posible vislumbrarla como la manifestación del deseo juanino de equipararse al resto de religiosos presentes en el archipiélago, integrantes de provincias religiosas con sede y cabeza en las islas filípicas. Sin embargo, es también reveladora de la conciencia de la diferencia y de la distancia que los juaninos filipinos guardaban respecto a su matriz mexicana, con sus decenas de hospitales regados a lo largo y ancho del poderoso y rico virreinato de la Nueva España.

Los juaninos filipinos no escogieron ser distintos, pues lo que era distinto fue el contexto en el que les tocó vivir; de hecho, algunas decisiones que les imprimieron su tan llevada y traída peculiaridad no fueran suyas, sino de otro, como fue el caso de la presencia de sacerdotes entre sus prelados, motivada por la Comisaría General novohispana por razones que aún se nos escapan. Pero lo que sí decidieron fue sobrevivir, primero, y ganarse un espacio después, en unas condiciones inéditas en el contexto de la expansión juandediana en el Nuevo Mundo. Así fue como sus vicarios provinciales asumieron la responsabilidad de nombrar a los priores del hospital de Cavite, habida cuenta la falencia de su matriz mexicana en cumplir con ese su derecho y obligación, atribución que, sin lugar a dudas, debió servir para fortalecer la autoridad de los también priores del hospital de Manila. Por otro lado, su apertura de noviciado fue una respuesta casi natural a una prohibición tajante y repetida pero que, por otra parte, no fue acompañada de un financiamiento continuo y estable de misiones que permitiesen atender a la numerosa clientela apiñada en sus hospitales, ya fuera en las camas, en los suelos o en las porterías, adonde también acudían sin cesar dolientes, pobres y desvalidos buscando acogerse a la hospitalidad, en su más antigua pero también en su más moderna acepción, practicada en los hospitales administrados por los hospitalarios de San Juan de Dios.

Es difícil que esas transgresiones fueran ignoradas por las autoridades civiles y eclesiásticas del archipiélago, pero en su tolerancia ante tales infracciones debe buscarse el impulso de una situación de carencia, una que sólo los habitantes de esa región marginal y fronteriza del imperio español estaban en condición de conocer. De esta forma, combinar la perenne y trabajosa tarea de la hospitalidad con la peculiaridad de un gobierno que no siempre se ajustó al modelo confeccionado para él en Madrid o en Nueva España constituyó, más que una desviación, una necesidad impuesta por esas partes tan remotas donde "valía tanto un español".

\section{BiBLIOgRAFÍA}

Alberro, S. 2005. Apuntes para la historia de la Orden Hospitalaria de San Juan de Dios en la Nueva España-México, 1604-2004. México: El Colegio de México - Orden Hospitalaria de San Juan de Dios.

Bautista Sandoval, J. E. 2011. "Las casas de la Buena Muerte, una búsqueda, una permanencia”. Bitácora 23: 32-36.

Constituciones de la Orden de la Hospitalidad de San Juan de Dios N. P. confirmadas por la Santidad de Urbano Papa VIII en 9 de noviembre de 1640. 1774. s/l: s/e.

Díaz-Trechuelo, L,. 1997. "La Casa de la Misericordia de Manila". En Actas del XI Congreso del Instituto Internacional de Historia del Derecho Indiano. T. IV: Buenos Aires: Instituto de Investigaciones de Historia del Derecho: 71-90.

Gómez, J. C. 1963. Historia de la Orden Hospitalaria de San Juan de Dios. Granada: Archivo Interprovincial.

Guerra, F. 1994. El hospital en Hispanoamérica y Filipinas, 1492-1898. Madrid: Ministerio de Sanidad y Consumo.

Maldonado de Puga, J. M. 1742. Religiosa Hospitalidad por los hijos del Piadoso Coripheo Patriarcha y padre de pobres San Juan de Dios en su provincia de San Raphael de las islas Philipinas. Granada: Imprenta de José de la Puerta.

Manchado López, M. M. 1999. "Religiosidad femenina y educación de la mujer indígena en Filipinas. El beaterio-colegio de la madre Paula de la Santísima Trinidad". Revista de Indias LIX-215: 171-202.

Martínez, D. 1756. Compendio Histórico de la Provincia de San Gregorio Magno de Philipinas de Religiosos Menores Descalzos de San Francisco, Madrid: Imprenta de la viuda de Manuel Fernández y del Supremo Consejo de la Inquisición.

Martínez Gil, J. L. 2003. "Execuátur Pontificio. Placet Regio de las Bulas". Archivo Hospitalario 1: 93-116.

Martínez Ruiz, E. 1998. Diccionario de Historia Moderna de España. I. La Iglesia. Madrid: Istmo.

Muriel, J. 1990. Los hospitales de la Nueva España. T. I: México: UNAMCruz Roja Mexicana.

Parra y Cote, A.1987. Bulario de la Orden Hospitalaria de San Juan de Dios. Granada: Orden Hospitalaria de San Juan de Dios.

Pérez Puente, L. 2010. El concierto Imposible. Los concilios provinciales en la disputa por las parroquias indígenas (México, 1555-1647). México: IISUE-UNAM.

Rocher Salas, A. 2010. La disputa por las almas. Las órdenes religiosas en Campeche, siglo XVIII. México: CONACULTA.

- 2005. La provincia del Espíritu Santo de San Juan de Dios de Nueva España, en A. Gutiérrez Escudero, y M. L. Laviana Cuetos (Coords.). Estudios sobre América, siglo XVI-XX. Sevilla: Asociación Española de Americanistas: 1299-1316.

Santos, J. [1715] 1977. Cronología hospitalaria y resumen historial del glorioso patriarca San Juan de Dios. Tomos I-II: Madrid: Orden Hospitalaria de San Juan de Dios.

San Antonio, J. F. de. 1738. Chrónicas de la apostólica Provincia de San Gregorio de Religiosos Descalzos de N. P. S. Francisco en las Islas Filipinas, China, Japón, \&. Manila: Imprenta de la Provincia.

Santa Inés, F. de. 1892. Crónica de la Provincia de San Gregorio Magno de religiosos descalzos de N. P. S. Francisco en las Islas Filipinas, China, Japón, etc., escrita en 1676. T. I: Manila: Litografía de Chofre y Compañía. 